\title{
Iron Age Mnemonics: A Biographical Approach to Dwelling in Later Prehistoric Britain
}

\author{
Lindsey Büster $\odot$
}

\begin{abstract}
Domestic architecture played a central role in the identity of later prehistoric communities, particularly in creating lasting bonds between the living and the dead. Acting as a conduit of memory and legacy for successive generations of inhabitants, roundhouses straddled the divide between house and memorial. The exceptionally well preserved Late Iron Age settlement at Broxmouth in southeast Scotland demonstrates the potential of biographical approaches in understanding the central role that roundhouses played in fashioning the identity of successive households, and the role of objects in constructing genealogical narratives.
\end{abstract}

\section{Introduction: ritualizing the domestic sphere}

Domestic architecture has long been recognized as representing more than a passive backdrop to everyday life (e.g. Carsten \& Hugh-Jones 1995; Hillier \& Hanson 1984; Parker Pearson \& Richards 1994) and houses as 'living participants in prehistoric social action' (Bailey 1990, 20). This is particularly true in later prehistoric Britain, where specialized ritual monuments are extremely rare and the domestic sphere becomes the focus for ritualized action in ways which are not characteristic of earlier periods (e.g. Bell 1992; Bradley 2003; Hill 1995). Far from reflecting zones of activity undertaken in the course of daily life, many artefacts recovered from Iron Age roundhouses were not the result of casual loss or abandonment, but were deliberately deposited in highly structured ways (e.g. Webley 2007). These so-called structured deposits (cf. Hill 1995; see Garrow 2012 for a full discussion) are often associated with the foundation and abandonment of buildings, though I will demonstrate that they also occur at important 'transitional' moments within the life of the household. It is thus the selective deposition of material by Iron Age communities (rather than the products of casual loss and discard) that we often observe in the archaeological record (Bradley 2005, 208-9). Brück (1999a) has demonstrated the pitfalls of drawing distinctions between ritual and rationality, sacred and profane, in pre-modern and non-western societies, but notwithstanding these arguments, it becomes clear that in many cases roundhouses reveal more to us about their social and cosmological role in people's ontological understandings of the world than the 'practicalities' of everyday life: a reversal of Hawkes' (1954) 'Ladder of Inference'.

\section{'The living house': houses as ancestors}

It [the Maori meeting house] was simultaneously regarded as a living being and as a way of representing the passage of time. (Bradley 2005, 51)

The study of houses in terms of their 'life histories' (e.g. Tringham 2000, 127), 'life cycles' (Bailey 1990, 28; Brück 1999b) and later, their 'biographies' (e.g. Sharples 2010), is well established. This has grown from an understanding-based, for example, on ethnographic evidence from the Batammaliba of Togo and Benin Republic (e.g. Blier 1987) or the Zafimaniry of Madagascar (Bloch 1995a), and archaeological evidence such as 'single phase' Middle Bronze Age roundhouses in southern Britain (Brück $1999 \mathrm{~b}$ ) or the wandering settlements of the later prehistoric Netherlands (Gerritsen 1999) — that, in many societies, a close temporal affiliation exists between

Cambridge Archaeological Journal 31:4, 661-674 (C) The Author(s), 2021. Published by Cambridge University Press on behalf of the McDonald Institute for Archaeological Research. This is an Open Access article, distributed under the terms of the Creative Commons Attribution licence (http://creativecommons.org/licenses/by/4.0/), which permits unrestricted re-use, distribution, and reproduction in any medium, provided the original work is properly cited.

doi:10.1017/S0959774321000263 Received 12 Jul 2019; Accepted 26 Mar 2021; Revised 22 Mar 2021 
the development of a physical 'house' and the natural cycles of the social 'household'. In New Ireland (Küchler 1987), as Gerritsen points out, 'the house does not survive its inhabitant' $(1999,82)$ and in this way, 'house and inhabitants are commensurable' $(1999,81)$. More recently, however, with the material turn and more symmetrical frameworks of interpretation regarding human and non-human actants (e.g. Latour 2005), biographical approaches have been criticized as over-anthropocentric (Joyce \& Gillespie 2015), with a move towards concepts such as 'itinerary' (Joyce 2015). These criticisms of biography are valid in many cases, especially in relation to artefact studies where the approach was first and is perhaps most widely employed (e.g. Gosden \& Marshall 1999; Joy 2009). As Joyce $(2015,28)$ points out, 'objects ... are not actually much like people', and the study of their biographies necessitates multiple 'reincarnations' or cycles of life and death. Nevertheless, one could say that people are not much like people either, if one takes, for example, the circulation after death of plastered skulls in Neolithic southwest Asia or the Christian relics of Medieval Europe: these 'people' too outlive such constrained implementations of biography.

Turning back to domestic architecture, we know from ethnographic accounts that houses can be perceived as human bodies. In the Maori meeting house (van Meijl 1993), for example, veranda=face, porch= brain, ridge-pole=spine etc., while amongst the Batammaliba of Africa (Boivin 2004a), the clay used to make houses is akin to flesh and the clay-based plaster applied to the surfaces of walls is referred to as 'skin'. Similarly, Eriksen's (2016) study of Viking longhouses reveals etymological origins for architectural elements in human body parts ('window'=vidauge=' wind eye', 'gable'=gavl/geblan='head, skull', etc.), and 'footprint' is still used today in English to refer to the ground-plan of a building. Taken together with the apparent 'cremation' and 'burial' of some high-status halls (which may well have had names), Eriksen argues that we should not perceive houses in these societies merely as representations of bodies but actual bodies. She prefers to see Viking longhouses as 'house-bodies', in much the same way as, for example, Alberti \& Marshall (2009) describe ceramic vessels in first-millennium AD northwest Argentina as 'body-pots'. Indeed, perceiving only representation and metaphor risks viewing the past through a post-Enlightenment, Cartesian lens which separates humans from their material world. As such, the biographical study of a house (and particularly the house(s) which I present below) is not in conflict with a flat ontological framework and in fact enhances our understanding of the relational identities of house and inhabitants. Biographical approaches place buildings at centre-stage, rather than relegating them to supporting roles in anthropocentric narratives.

\section{‘Nested' and 'cyclical' biographies}

On long-lived sites, choices by one generation of inhabitants would have been constrained and shaped by the decisions of their predecessors (cf. Gosden \& Lock 1998, 3); their presence would be continually felt and reflected upon, not least through the material remains encountered (frequently and unintentionally) in the course of everyday life. The partial subsidence of House 2 at the Late Neolithic site of Opovo in Serbia due to its construction over a former infilled well (Tringham 2000, 123) is just one example, and is mirrored at the Iron Age hillfort of Broxmouth in southeast Scotland (see below) by the slumping of a series of Middle Iron Age roundhouses into the infilled ditch over which they were built (Armit et al. 2013, 93). Such frequent encounters with the past (in the past) highlight that the division of continuously occupied, long-lived sites (whether they be whole settlements or individual housestances) into distinct 'phases' of activity artificially divides their biographies into discrete episodes, conceptually severing these intimate ties between generations. Instead, we might think of biographies operating simultaneously at a variety of scales, from settlements and their surrounding landscapes stretching back into ancestral or 'mythical' time to (in a British Iron Age context) ramparts or gateways refurbished every few decades, and smaller features such as grain-storage pits or animal byres having annual cycles, and so on. Any inhabitant living within this settlement may draw, perhaps simultaneously, on all of these temporal and spatial references in the formulation of their own social identity. In order to reflect this adequately, we must replace single overarching biographical frameworks with concepts of 'nested' biographies which can simultaneously situate the individual, the household and the community at various scales in space and time (Fig. 1).

Furthermore, since the 'conception' of a structure draws on a pre-existing settlement landscape, can we really think of biographies as linear phenomena with distinct beginnings and ends? With careful maintenance, individual houses can often 'outlive' their human occupants; analysis of Neolithic houses at Çatalhöyük, Turkey, for example, indicates that the use-lives of individual house posts could extend over several generations (Hodder 2012, 194, fig. 9.8). As such, houses themselves can become central figures in the biographical narratives of successive 
Figure 1. Biographies, like identities, are nested, and different aspects of the archaeological record can inform us about identities at different social scales. Although depicted as a series of circles, in reality the categories are far more blurred, and ultimately relational to one another. The use of a sphere is designed to indicate that each scale of biography has both a spatial and temporal dimension.

Figure 2. The cyclical nature of roundhouse biographies, with increasing layers of social memory added with the completion of each successive cycle (after Büster 2012). The actions accompanying each 'stage' are illustrative rather than exhaustive.
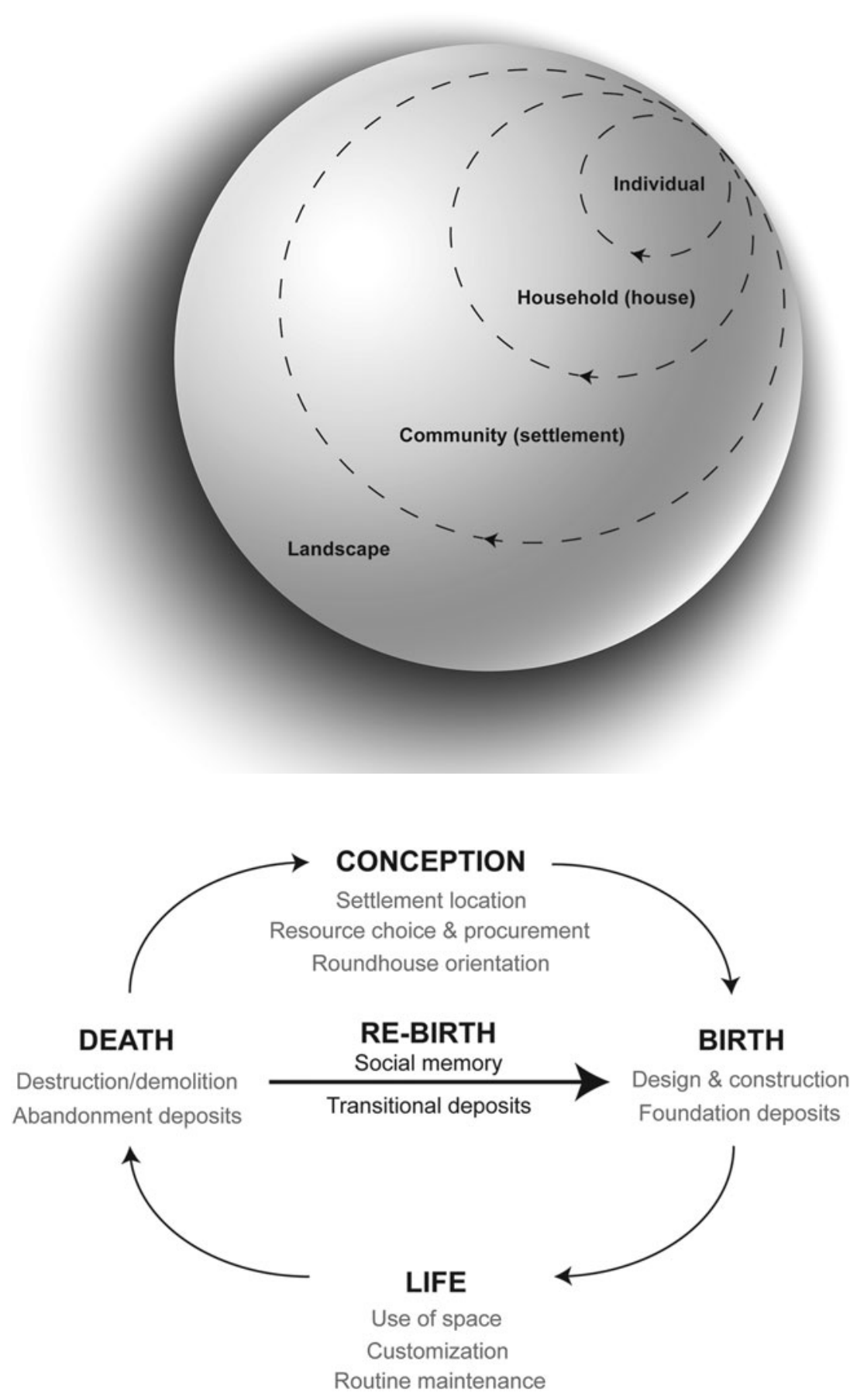

Having said this, focusing on the conventional households, and may have been vehicles through which people articulated relationships with past, present and future (Gerritsen 2008, 148-9; Gosden 1997, 304). The biography of these buildings is therefore not only nested, but also cyclical (Fig. 2). Each re-birth would have imbued the structure, and its household, with ever deeper layers of social memory, onto which the identity of the new household was grafted. biographical stages of conception, birth, life and death will, of course, obscure the smaller episodes of transformation which a building (and its inhabitants) may undergo during its/their lifetime (many of which will be invisible archaeologically). Ethnographic evidence, and rare archaeological cases where finer-grained resolution is possible, alert us to these more subtle episodes of change. At Çatalhöyük, for example, 
micromorphological analysis of house walls has identified up to 700 re-plastering episodes, over a period of roughly 70 years; that is, around one per month (Hodder \& Cessford 2004, 22; Matthews 2004). In rural Rajasthan, certain parts of the Balathal roundhouse are re-plastered not only to purify the building upon the birth or death of an individual, but also on a more frequent basis, for example, when visitors are expected, or to demarcate a change in function of particular areas (Boivin 2004b, 172).

Closely linked to concepts of biography, and hardly divisible from any biographical approach to prehistoric architecture, is the material of the structures themselves (e.g. Bille \& Sørensen 2016). In many societies, certain substances and materials are perceived to be not only physically, but conceptually and symbolically, more or less appropriate for certain uses (Boivin \& Owoc 2004; Hurcombe 2007; Meskell 2005). Among the Ma'ohi of eastern Polynesia, for example, certain tree species, such as the breadfruit, were restricted to the construction of elite residences and sacred houses, and trees cut from sacred woods or those grown in temple precincts could only be worked by high-status specialists (Kahn \& Coil 2006, 342). Other construction materials may have been seen in a similar light. Returning to the Balathal houses of rural Rajasthan, the type of soil selected for re-plastering events is based on the nature of the space to be demarcated or the type of event referenced (Boivin 2004b); red-coloured soils are, for example, particularly auspicious and are used for sacred places within the home (such as areas around the hearth and places for prayer), as well as on special occasions such as weddings and festivals (Boivin 2004b, 171).

Renewal of structural fabric may also be necessary for cosmological as well as social reasons. The dulling and darkening of rock carvings through weathering is considered by both the San peoples of South Africa and Aboriginal communities in Australia to represent the reclaiming of the images by the spirit world, with frequent re-carving and re-painting required to maintain contact with the world of the living (Ouzman 2001; Taçon 2004, 39). As such, periodic replacement by past societies of various structural elements of the house may have been considered necessary to ensure the continued vivacity of structures and to renew conceptual links with previous generations in the maintenance of social identity.

\section{Transitional deposits}

Structured deposits are ubiquitous features of later prehistoric architecture, and appear to be associated with specific moments in the biography of buildings and their inhabitants. These deposits often seems to have accompanied either the foundation or abandonment of structures (e.g. Armit 2006, 247; Bender et al. 2007 , 150, fig. 6b, col. pl. 3b; Webley 2007), as is particularly clear, for example, in the 'wandering settlements' of the later prehistoric Netherlands (Gerritsen 1999) and single-phase roundhouses of the southern British Bronze Age (Brück 1999b). It is at these same sites that a traditional biographical framework of analysis has been relatively unproblematic. In Iron Age Britain, however, roundhouses can also be re-built on the same house-stance, blurring the division between one house biography (one household) and the next. In these cases, the idea of 'nested' and 'cyclical' biographies becomes more useful for their interpretation, and alerts us to the fundamentally different relationship between house and household in these communities. Furthermore, these extended biographies are necessarily reflected in less formal distinction between foundation and abandonment deposits, with the two being synonymous in a continual process of decay and renewal (see, for example, Nakamura \& Pels' 2014 discussion of deposits at Çatalhöyük). These may be better understood as transitional deposits, marking significant moments of transformation within the life of a structure and its household (just as we might understand rites of passage throughout the life of an individual). Thinking about deposits as transitional also helps us to overcome the building/living dichotomy and to acknowledge that the construction of architecture is never really 'finished', but is an ongoing process (Harris 2016; Ingold 2013).

\section{Ancestral homes: the Broxmouth roundhouses}

Having outlined the potential of biographical approaches in the study of later prehistoric architecture, I now want to apply the concept to the wellpreserved Late Iron Age (Phase 6) roundhouses at Broxmouth hillfort in southeast Scotland. Though biographical frameworks have been commonplace, for example, in the study of tell sites of Neolithic southwest Asia (e.g. Bailey 1990; Kay 2020), the timber architecture of later prehistoric roundhouses across much of the British Isles does not lend itself easily to such approaches. The exceptional survival of several structures at Broxmouth, due largely to their construction in stone (at least in later iterations), thus presents a rare opportunity to examine the social and cosmological role of the roundhouse in prehistoric identity over time.

The settlement at Broxmouth, which lay on the East Lothian coastal plain roughly $600 \mathrm{~m}$ from the 

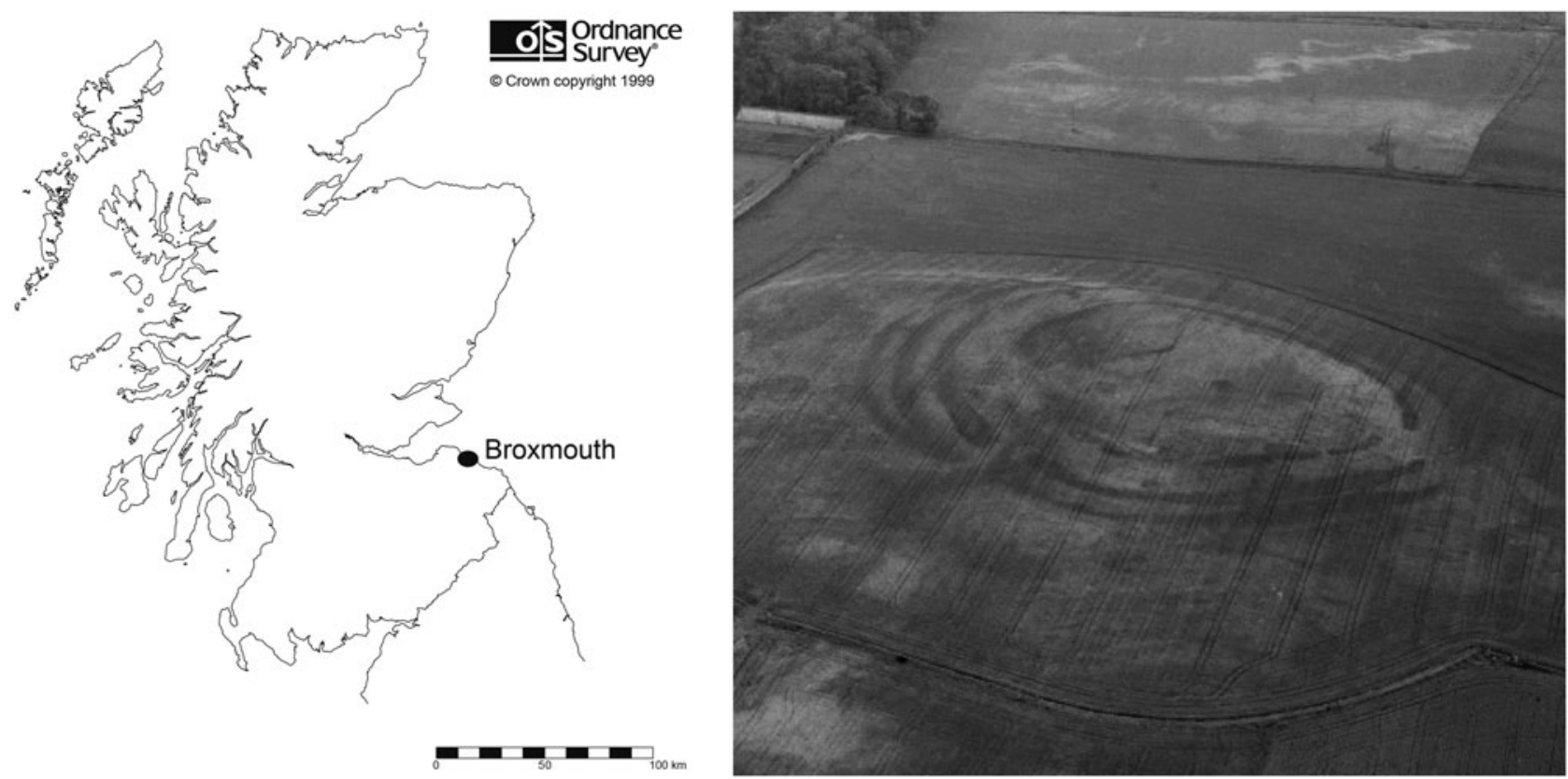

Figure 3. Broxmouth location map and aerial photograph of the site as a crop-mark. (SC 1323319 CHistoric Environment Scotland/John Dewar Collection.)

coast (Fig. 3), was occupied (apparently continuously) for around eight centuries (c. 600 BC-cal. AD 200) over some 32 generations (Armit \& McKenzie 2013, 513). Although the site is known as a hillfort, it began as an unenclosed settlement, and the multiple ramparts and ditches that developed later were maintained for only a couple of centuries. When the Phase 6 settlement (Fig. 4)—the last phase of occupation, with Bayesian modelled dates of c. 100 cal. BC-cal. AD 155-was established, some 20 generations after the site was first inhabited, it is likely that Broxmouth was a well-known place in the landscape, with its own 'history' and its own stories. Around a third of the 158 AMS dates indicate the presence of redeposited material across various phases of the site (Hamilton et al. 2013). This, together with the progressive truncation of features belonging to Phases 1-5 (with the exception of several Middle Iron Age houses surviving in sunken ditch fills or under ramparts), points to frequent encounters with the material remains of the past by the Late Iron Age inhabitants; not least, in the digging of scooped house-stances, wall-slots, pits and post-holes during construction and maintenance of the Phase 6 roundhouses. Burials within the settlement interior were apparently respected and protected by successive generations, and even appear to have influenced the location of some of the Phase 6 buildings, such as House 2, whose northernmost entrance post-hole was aligned on/located adjacent to a Phase 1 crouched inhumation. This demonstrates that the 'conception' of the Late Iron Age settlement (though ultimately erasing the material remains of its predecessors) was very much dictated by the material traces of the past.

The near-complete obliteration of features associated with the Phase 1-5 inhabitants of the hillfort lies in stark contrast to the Phase 6 roundhouses themselves, in which the retention and referencing of earlier occupation of house-stances (through several biographical cycles) became a central feature of their evolution. Several of the Phase 6 roundhouses (Houses 4, 5 and 7) displayed complex developmental sequences which saw them begin life as timber or partial timber structures with earthen floors and become slowly encased by stone walls and paved floors (Büster \& Armit 2013). Crucially, these modifications do not appear to have been structurally necessary: there is no evidence for instability in the existing roundhouse fabric. Furthermore, new walls (and later, paved surfaces) were not dismantled and replaced, but were built in front (and on top) of one another. There appears to have been no attempt to re-use the previous structural fabric, with the acquisition of new raw materials and re-building inside existing footprints not only requiring large investments of labour and materials, but ultimately compromising useable space within the roundhouse interior. In the case of House 4, which underwent the most (five) re-builds, the structure more than 


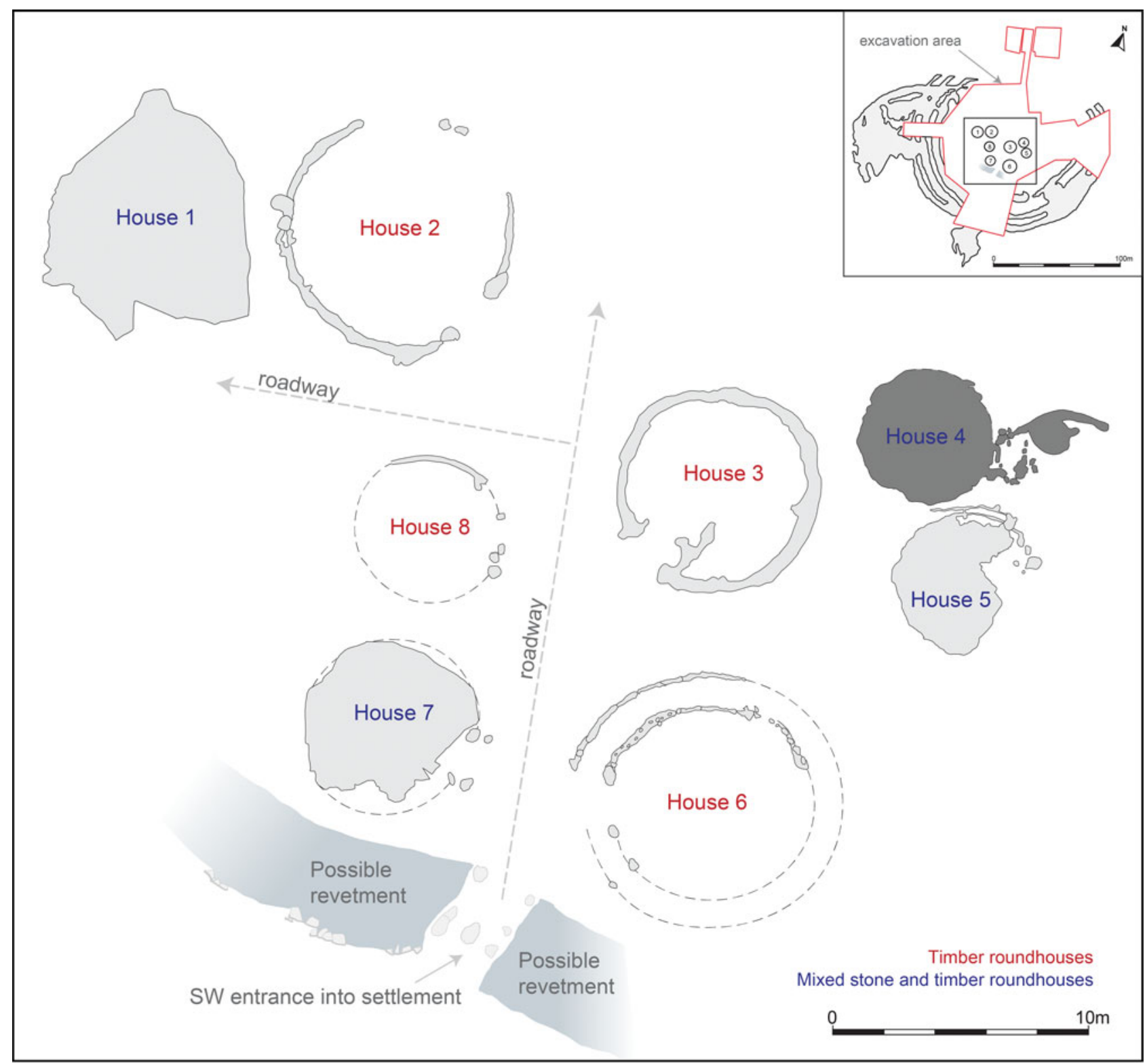

Figure 4. The surviving Phase 6 settlement, showing those roundhouses constructed in timber and those that included both timber and stone elements at some point during their life. It is likely that House 1 had a turf wall which did not survive later plough truncation.

halved in size, from 38.5 sq. $\mathrm{m}$ to a mere 15.2 sq. $\mathrm{m}$ in its final iteration (Fig. 5); this must have had a significant impact on its functional capabilities and the number of individuals and activities that it could accommodate. Furthermore, the sealing of large pits must also have had a profound effect on the functions performed within the building, with activities presumably having to be undertaken in new ways or moved to different buildings (see Kay 2020 for a similar discussion at Çatalhöyük).

\section{Generational turnover}

What is remarkable, at least in a British Iron Age context, is the resolution of the chronological framework for occupation at Broxmouth, as provided by AMS

Figure 5 (opposite). Plans and sections illustrating the biography of House 4 and the gradual decrease in its internal area over time (as indicated by the photographs of the stage 1 and stage 5 roundhouse). 

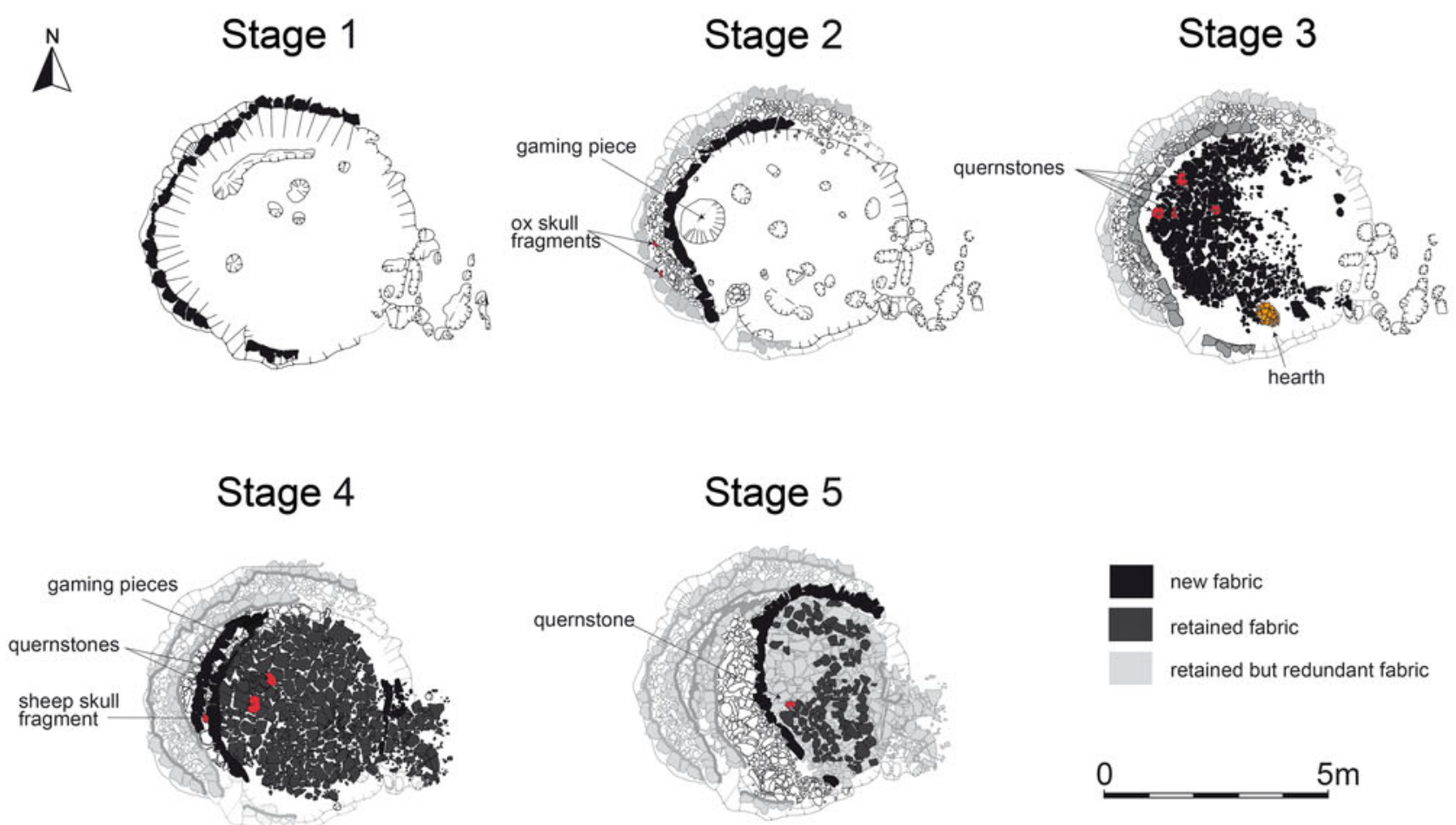

Stage 5

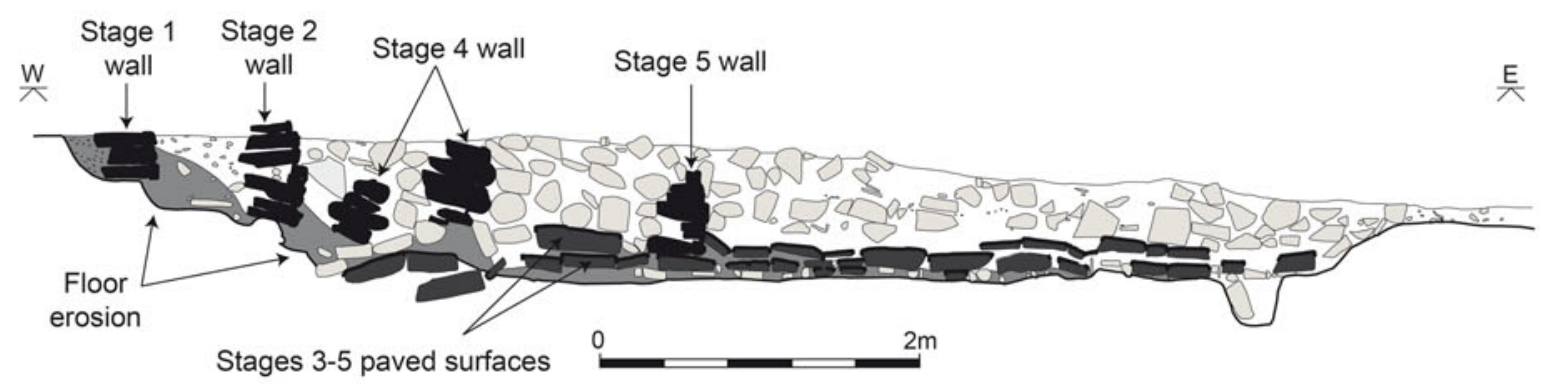

Stage 1

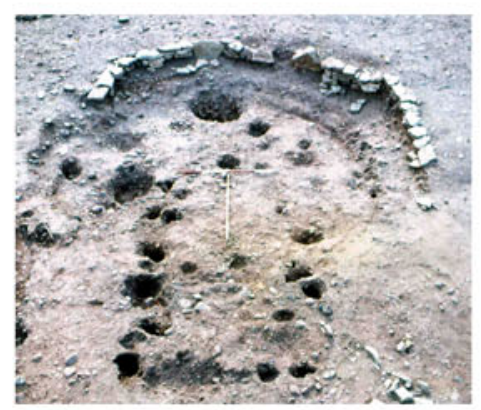

Stage 5

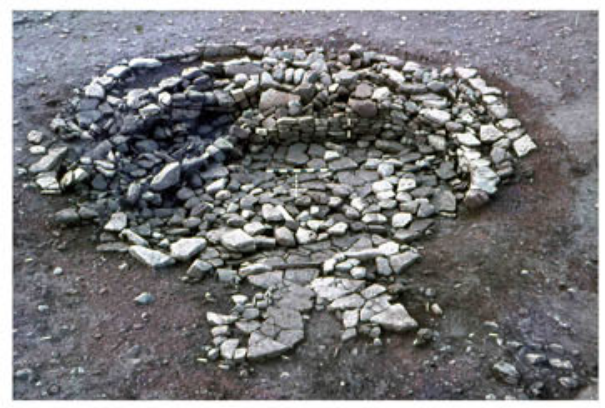




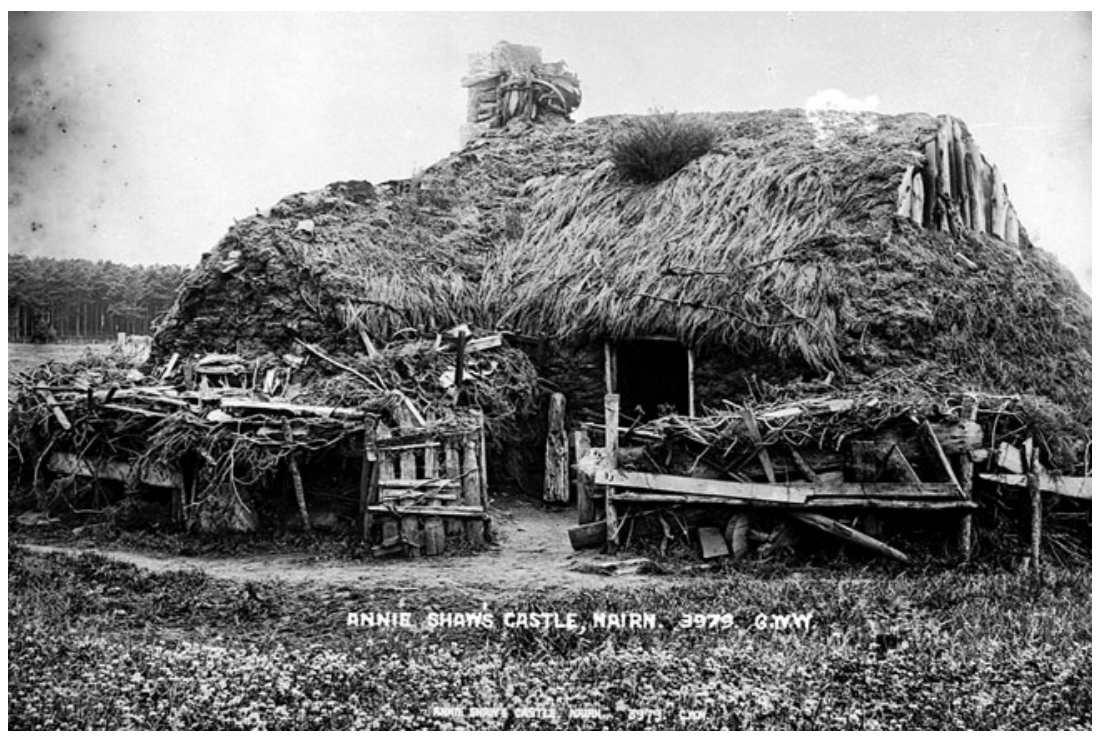

Figure 6. 'Annie Shaw's Castle', Nairn. (MS 379/E05211, University of Aberdeen.)

dating and Bayesian modelling of the site, and what this tells us about the tempo and rhythm of the changes taking place over its roughly 800-year history. Significantly, for the Phase 6 roundhouses, it tells us that the replacement of walls and paved surfaces appears to have taken place on a generational or bi-generational basis (i.e. roughly every 40-60 years: Büster 2012, 148; Büster \& Armit 2013, 151); the inherent error ranges of even Bayesian modelled AMS dates do not allow us to be more specific than this (Hamilton et al. 2013). This suggests that physical 're-structuring' of the roundhouse was central to the negotiation and communication of new identities at significant times in the life of the household, perhaps upon the loss (death) or addition of new members to the group, as Brück (1999b) and Gerritsen (1999) have suggested in the respective studies discussed earlier.

What is also significant is that the material manifestation of the Broxmouth roundhouses appears to have been integral to this identity building. We have already noted that when each successive modification took place-when each new skin was grafted onto the roundhouse-the previous structural fabric was left intact. In this way, the stone walls of previous generations of Broxmouth inhabitants not only metaphorically, but physically, territorialized the assemblages of inhabitants (people, animals, objects, ancestors) within (cf. Harris 2016; Maxwell \& Oliver 2017; Normark 2009). This piecemeal approach to maintenance has been noted in the vernacular architecture of more recent times, and has created visible cumulative biographies: ad hoc repair (with the retention of earlier structural fabric) undoubtedly provided 'Annie Shaw's Castle' with a visible ancestry and elevated its status to recognized and important local landmark (Fig. 6); note here the bipartite name of house and occupant (one giving identity to the other).

We have also noted that several of the Broxmouth roundhouses (e.g. Houses 4,5 and 7) began their life in timber, or partially in timber, and gradually became encased in stone (Büster \& Armit 2013). As such, prehistoric communities may have shared similar attitudes towards the affordances of stone and timber to those witnessed among ethnographically documented societies in Madagascar. In these societies, wood is used to build houses of the living while stone is reserved for the tombs and standing stones of the ancestors (cf. Parker Pearson \& Ramilisonina 1998, 311), reflecting a cosmology in which biological and social ageing is conceptualized as a kind of 'hardening' (Bloch 1995a; 1995b, 215). Through periodic and successive transformation (through their multiple 'lives'), the Broxmouth roundhouses may thus have served as the material manifestations of the history of lineages: epitaphs and memorials for the many generations of inhabitants which had called them home. This is perhaps particularly pertinent in a society which had no normative funerary tradition of formal cemeteries or grave monuments, instead choosing to incorporate the dead into the communities of the living, frequently within the fabric of roundhouses themselves (Armit \& Ginn 2007; Brück 1995). In this sense, a structure like House 4, with both old and new skin, may have been considered as a physical and conceptual bridge between past and present, between the world of the living and the world of ancestors. 


\section{Family ties and continuing bonds}

The [Maori meeting] house was not a surviving trace of the ancestor's existence and agency at some other, distant, coordinates, but was the body which he possessed in the here and now, and through which his agency was exercised in the immediate present. (Gell 1998, 253)

As is characteristic of many Iron Age roundhouses, structured deposits were abundant within the fabric and features of the Phase 6 buildings at Broxmouth, whose earthen floors had been deeply eroded by frequent sweeping-out of any casual or accidental debris: erosion which appears to have prompted the laying of the first paved floors in Houses 4, 5 and 7. Cached objects of this kind have often been described in terms of foundation and abandonment deposits, but the successive re-building of structures on the same house-stances at Broxmouth, and the nesting of buildings inside one another, necessitates that we conceptualize them as transitional deposits between one roundhouse (or one household) and the next, and as marking the careful negotiation of past and present.

Links between past and present at Broxmouth are further demonstrated by a) the types of material chosen for deposition and b) the locations of these materials. These attest to the careful referencing (or citation: Borić 2003) of previous structures (and households) by successive inhabitants. Ox-skull fragments placed at the base of the wall during the initial construction of House 4 are, for example, mirrored by the deposition of a sheep skull at the base of the wall in the fourth iteration of the roundhouse (Büster \& Armit 2013, 141-7; Fig. 7). Another mechanism for linking past and present in House 4 can be seen in the incorporation of deliberately broken quernstones into the paved surface of the stage 3 roundhouse, and their placement over the largest of the stage 2 pits (Büster \& Armit 2013, 143-7). Old and broken quernstones represent an obvious raw material for paving slabs, but (as is common with this particular artefact type) the deliberate fragmentation in some of the Broxmouth examples (McLaren 2013, 317), and their deposition over earlier features, suggest that they were being used in a more deliberate way. The upper rotary quernstone overlying the large stage 2 pit may even have provided a more direct and tangible bond between past and present, in that the feeder-pipe would have facilitated, for example, the pouring of votive libations into the feature below (Fig. 8); a similar interpretation has been proposed by Campbell $(1991,133)$ at Sollas wheelhouse in North Uist. Another example of this

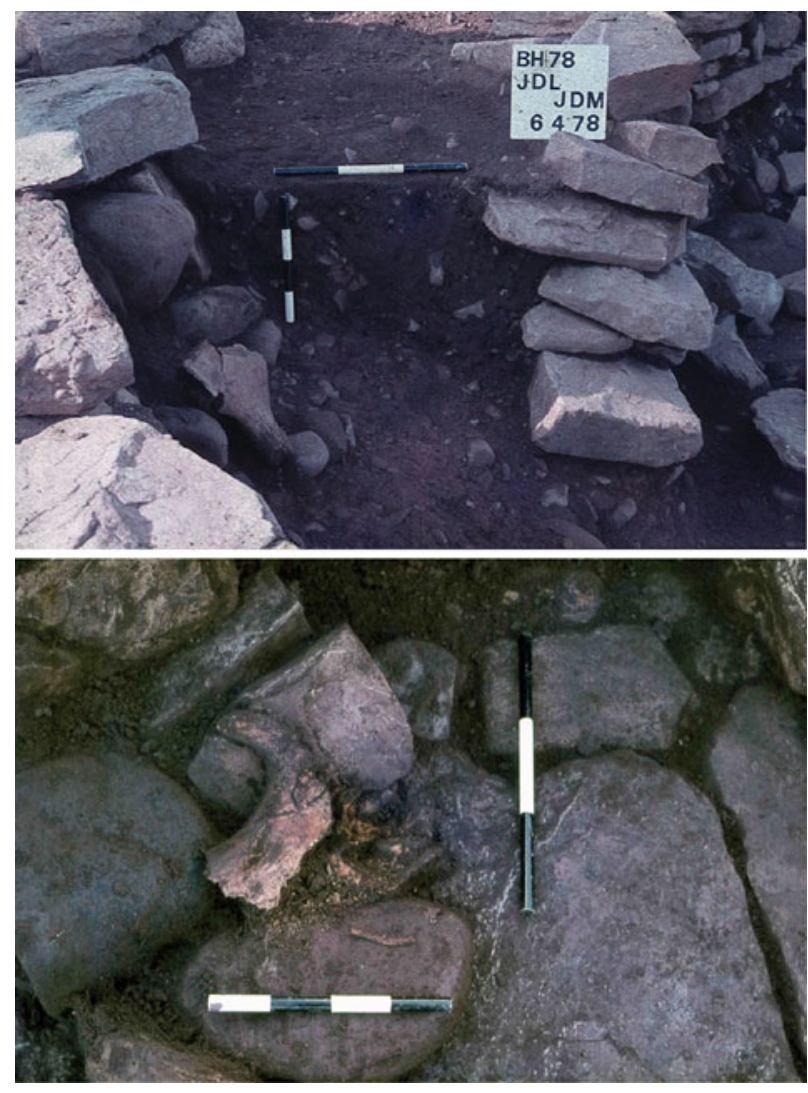

Figure 7. Fragments of ox skull (top) and sheep skull (bottom) deposited between wall facings during construction of the stage 2 and stage 4 modifications to House 4.

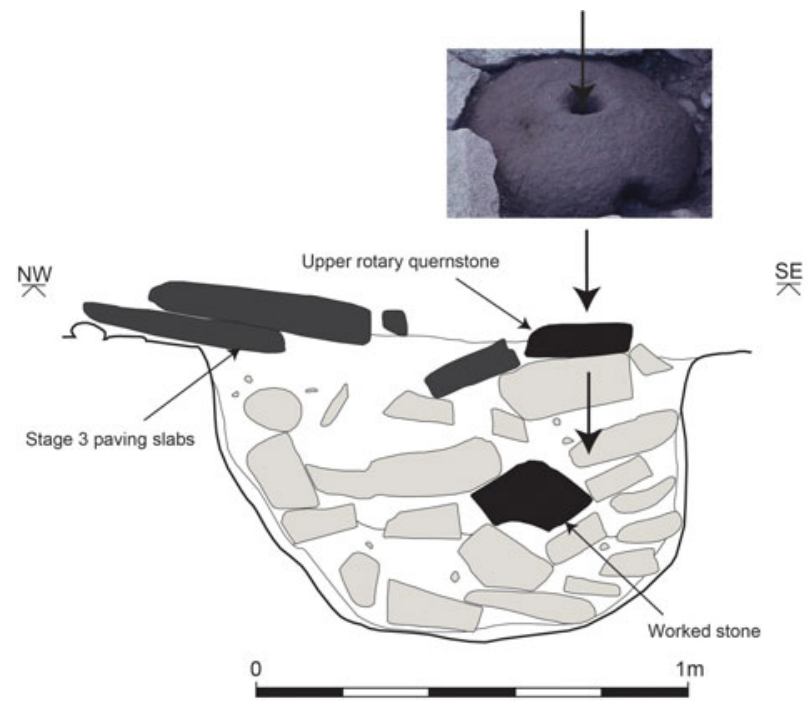

Figure 8. Upper rotary quernstone overlying a large stage 2 pit in House 4. 

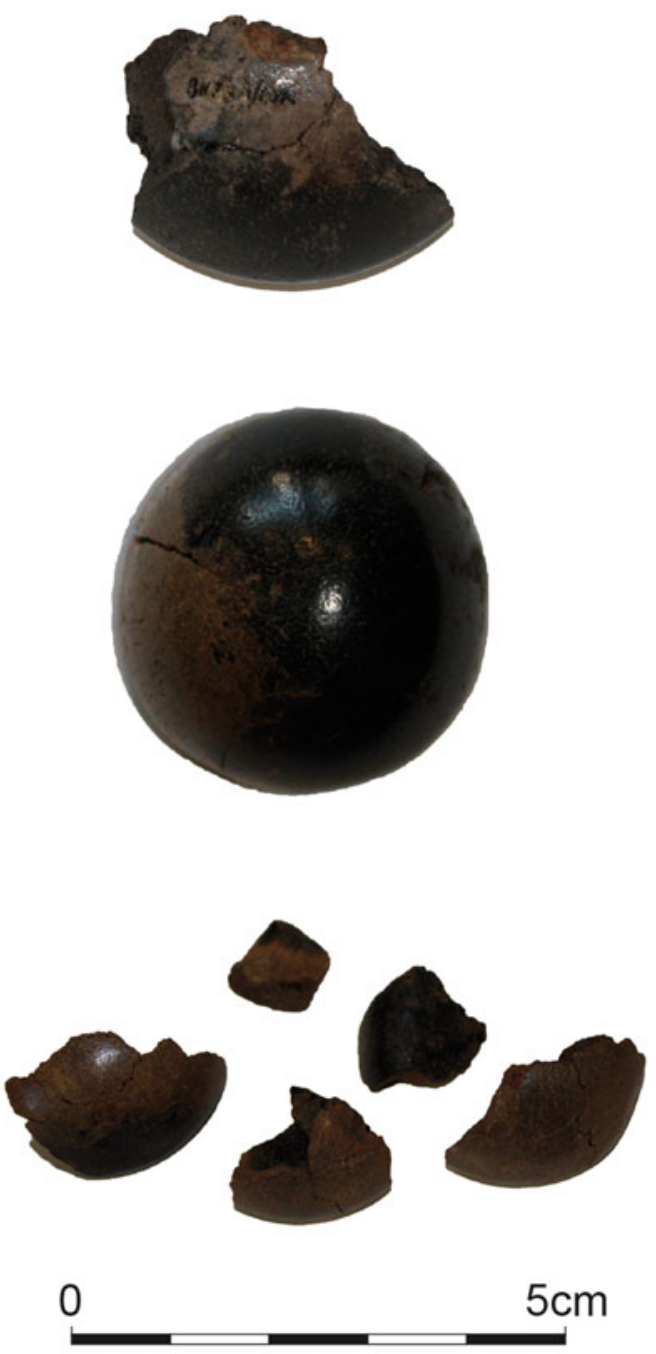

Figure 9. Group of three antler gaming pieces (probably belonging to the same set). The bottom piece (now very fragmentary) was deposited in the large pit shown in Figure 8, while the upper two were deposited several generations later at the base of the stage 4 wall. (Photographs courtesy of National Museums Scotland.)

phenomenon (albeit in a more conventional funerary context) is provided by the first-century BC cemetery complex at Goeblingen-Nospelt in Luxembourg, where a large ceramic vessel known as a dolium was (having had its base removed) placed over the grave chamber of a high-status female and formed a focus for offerings for at least 175 years (Metzler \& Gaeng 2009, 501-8; Fernández-Götz 2016, 175, fig. 9).

A more overt physical tie between successive generations of inhabitants of House 4 is represented by three antler gaming pieces (Fig. 9). These artefacts are unique to House 4 and are likely to have belonged to the same set. One of the gaming pieces was deposited during the infilling of the large pit (mentioned previously) which dominated the interior of the stage 2 roundhouse, while the other two were deposited during construction of the wall in the fourth iteration of the structure, some considerable time (and several generations) later. Presumably, these latter pieces were deliberately kept and cherished, possibly even played with. The playing of games is a recreational activity-literally 'recreating the world through the reordering of reality' (Hall 2007, 1). These highly personal and tactile items (perhaps associated with a known, named individual) would thus have been particularly powerful as visual prompts for stories surrounding previous households and /or specific individuals, and in this tangible way would have created 'continuing bonds' between the living and the dead.

Finally, we must consider two apparently 'ordinary' but no less significant items: two bone 'spoons' that were deposited during construction of the stage 1 and stage 5 walls of House 4 (Fig. 10). These represent the first and last deliberately deposited artefacts in House 4 (at least in terms of what we can recognize archaeologically), and they mirror each other not only in form but in the context of their deposition: tucked under successive walls of the roundhouse, at least five generations apart, and thus bracketing the use of this long-lived structure. As with the gaming pieces, it is interesting that these are small, personal and tactile objects. We cannot know the period of time over which specific oral traditions survived, but these paired deposits must be more than mere coincidence, and the deposition of the latter example appears to make deliberate reference to the former. Implying the retention of memories over such a long period of time in non-literate societies might seem like a stretch, but ethnographic evidence tells us that genealogical histories can persist for up to around 500 years (Ballard 1994), and similar time-depths are suggested for Maori oral traditions concerning the identity of particular houses (cf. Best 1927, 96). We can similarly envisage that the recounting of stories concerning household identity would have been ubiquitous in prehistoric communities, perhaps aided by similar objects to those described above (cf. Ahmed 2004; Harris 2010).

We are forced to consider, then, whether the Phase 6 roundhouses at Broxmouth (or at least some of them), and House 4 in particular-which experienced the most re-builds and saw deposition of the most structured transitional deposits within its fabric-gradually took on the role of epitaph for particular households or genealogies: transformed over time into a 'memory-box' for the Broxmouth community. It is not insignificant that many of the artefacts deposited so deliberately 
and with such careful referencing of one another were hidden from view as the roundhouse was built up around them; this may have necessitated and reinforced the need to tell and re-tell stories to keep their memory (and the memory of their owners) alive; to know these stories was to be part of the community.

During final abandonment of the Phase 6 settlement, the scooped house-stances were deliberately infilled. Since they represented the last settlement activity at Broxmouth, infilling presumably did not take place to level the site for future occupation; the houses appear to have been deliberately 'buried' (cf. Eriksen 2016). Significantly, AMS dates suggest that some of the infill material pre-dated the Phase 6 settlement by several hundred years and must therefore have been dug from older middens on the site, either for the deliberate infilling of these structures at the end of their lives, or incorporated into the original structural fabric, which subsequently collapsed or was deliberately toppled (Büster 2012, 144; Büster \& Armit 2013, 150). In this final act of infilling we see the unification of the various generations of the Phase 6 inhabitants of Broxmouth into the realm of ancestors, and the transfer of the whole community into an agglomerated past where individual and communal, recent and mythical identities were united.

\section{The social role of later prehistoric architecture}

Consideration of the animated nature of domestic architecture in many societies around the world today, and archaeological evidence pointing to the close temporal association of house and household in the past, has demonstrated the continued value of biographical approaches in understanding the central role that these structures played in the lives of prehistoric communities. Analysis of the Late Iron Age roundhouses (and House 4 in particular) at Broxmouth has, however, demonstrated the limitations of conceptualizing biographies as unilinear trajectories moving through distinct categories from birth to death. Instead, we are confronted with the indivisibility of temporal scales (from deep, mythical past to everyday life) and the nested, cyclical and relational nature of biographies with blurred categorical horizons. The Broxmouth roundhouses have demonstrated that the very fabric of people's homes, and the deposition of emotionally and mnemonically charged objects (cf. Harris 2010) within them, was central to the maintenance and negotiation of social identities at a number of scales. Furthermore, detailed consideration of the location and composition of such deposits has demonstrated
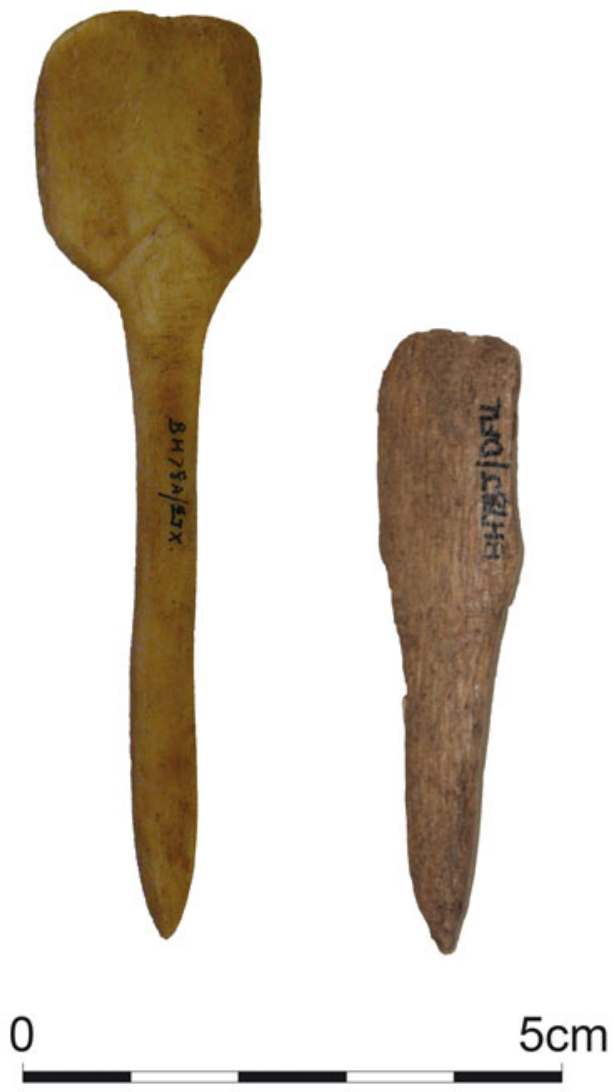

Figure 10. Two bone 'spoons' (deposited some five or more generations apart) at the base of the stage 1 and stage 5 walls during their construction. (Photographs courtesy of National Museums Scotland.)

that the spatial referencing and curation of objects was central to the creation and maintenance of enduring ties with the past, and the fundamental role of oral tradition in the communication and negotiation of identity across generations.

Though the specific nature of roundhouse construction and survival at Broxmouth lends itself to detailed biographical study, these buildings are by no means unique. Where stone superstructures survive, such as in the roundhouses of Atlantic Scotland, structured deposits are ubiquitous (e.g. Armit 2003; 2006; Campbell 1991; James \& McCullagh 2003) and remind us that complex, longlived biographies were far more common than the floor plans of long-decayed and plough-truncated contemporary timber structures suggest. In a period lacking formal funerary monuments, and with a close physical relationship between the living and the dead in the domestic sphere, it comes as no surprise that houses played important roles in the formation of social identities for households and communities, and bound one generation to the 
next. Only by taking a more nuanced biographical approach, within high-resolution Bayesian frameworks, can we begin to unlock any real understanding of what it meant to call a roundhouse a home for the communities of Iron Age Britain.

\section{Note}

1. Continuing bonds is a theory developed in contemporary studies of death, dying and bereavement (e.g. Klass et al. 1996; Stroebe et al. 2012; Walter 1996), and though not the focus of the present discussion, its applicability in archaeological contexts (and to archaeological interpretation) is being increasingly recognized (e.g. Büster et al. 2018, 268-70; Croucher 2018; Croucher et al. 2020). Indeed, the concept of maintaining 'continuing bonds' with the dead through material culture (such as curated artefacts) might be especially important in societies with no formal burial tradition, such as those of Iron Age Britain (Büster in press).

\section{Acknowledgements}

The doctoral research upon which this paper is based was funded by the Arts and Humanities Research Council (AHRC) and was undertaken as part of the Broxmouth Project, funded by Historic Environment Scotland. Thanks to Agni Prijatelj, Barbora Wouters, Ian Armit and two anonymous reviewers for their constructive comments.

$$
\begin{array}{r}
\text { Lindsey Büster } \\
\text { Department of Archaeology } \\
\text { University of York } \\
\text { King's Manor } \\
\text { Exhibition Square } \\
\text { York YO1 7EP } \\
\text { UK } \\
\text { Email: lindsey.buster@york.ac.uk }
\end{array}
$$

\section{References}

Ahmed, S., 2004. The Cultural Politics of Emotion. Edinburgh: Edinburgh University Press.

Alberti, B. \& Y. Marshall, 2009. Animating archaeology: local theories and conceptually open-ended methodologies. Cambridge Archaeological Journal 19(3), 344-56.

Armit, I., 2003. Towers in the North: The brochs of Scotland. Stroud: Tempus.

Armit, I., 2006. Anatomy of an Iron Age Roundhouse: The Cnip Wheelhouse excavations, Lewis. Edinburgh: Society of Antiquaries of Scotland.

Armit, I. \& V. Ginn, 2007. Beyond the grave: human remains from domestic contexts in Atlantic
Scotland. Proceedings of the Prehistoric Society 73, 113-34.

Armit, I. \& J. McKenzie, 2013. An Inherited Place: Broxmouth hillfort and the south-east Scottish Iron Age. Edinburgh: Society of Antiquaries of Scotland.

Armit, I., R. Kershaw \& J. McKenzie, 2013. Phase 4: the post-hillfort settlement, in An Inherited Place: Broxmouth hillfort and the south-east Scottish Iron Age, by I. Armit \& J. McKenzie. Edinburgh: Society of Antiquaries of Scotland, 93-102.

Bailey, D.W., 1990. The living house: signifying continuity, in The Social Archaeology of Houses, ed. R. Samson. Edinburgh: Edinburgh University Press, 19-48.

Ballard, C., 1994. The centre cannot hold: trade networks and sacred geography in the Papua New Guinea highlands. Archaeology in Oceania 29(3), 130-48.

Bell, C., 1992. Ritual Theory, Ritual Practice. Oxford: Oxford University Press.

Bender, B., S. Hamilton \& C. Tilley, 2007. Stone Worlds: Narrative and reflexivity in landscape archaeology. Walnut Creek (CA): Left Coast Press.

Best, E., 1927. The Pa Maori. (Dominion Museum Bulletin No. 6.) Wellington: Whitcombe \& Tombs.

Bille, M. \& T.F. Sørensen (eds), 2016. Elements of Architecture: Assembling archaeology, atmosphere and the performance of building spaces. London: Routledge.

Blier, S.P., 1987. The Anatomy of Architecture: Ontology and metaphor in Batammaliba architectural expression. Cambridge: Cambridge University Press.

Bloch, M., 1995a. The resurrection of the house amongst the Zafimaniry of Madagascar, in About the House: Lévi-Strauss and beyond, eds J. Carsten \& S. Hugh-Jones. Cambridge: Cambridge University Press, 69-83.

Bloch, M., 1995b. Questions not to be asked of Malagasy carvings, in Interpreting Archaeology: Finding meaning in the past, eds I. Hodder, M. Shanks, V. Buchli, J. Carman, J. Last \& G. Lucas. London: Routledge, 212-15.

Boivin, N., 2004a. From veneration to exploitation: human engagement with the mineral world, in Soils, Stones and Symbols: Cultural perceptions of the mineral world, eds N. Boivin \& M.A. Owoc. London: UCL Press, $1-29$.

Boivin, N., 2004b. Geoarchaeology and the goddess Laksmi: Rajasthani insights into geoarchaeological methods and prehistoric soil use, in Soils, Stones and Symbols: Cultural perceptions of the mineral world, eds N. Boivin \& M.A. Owoc. London: UCL Press, 165-86.

Boivin, N. \& M.A. Owoc (eds), 2004. Soils, Stones and Symbols: Cultural perceptions of the mineral world. London: UCL Press.

Borić, D., 2003. 'Deep time' metaphor: mnemonic and apotropaic practices at Lepenski Vir. Journal of Social Archaeology 3(1), 46-74.

Bradley, R., 2003. A life less ordinary: the ritualization of the domestic sphere in later prehistoric Europe. Cambridge Archaeological Journal 13(1), 5-23.

Bradley, R., 2005. Ritual and Domestic in Prehistoric Europe. London: Routledge. 
Brück, J., 1995. A place for the dead: the role of human remains in Late Bronze Age Britain. Proceedings of the Prehistoric Society 61, 245-77.

Brück, J., 1999a. Ritual and rationality. European Journal of Archaeology 2(3), 313-44.

Brück, J., 1999b. Houses, lifecycles and deposition on Middle Bronze Age settlements in southern England. Proceedings of the Prehistoric Society 65, 145-66.

Büster, L., 2012. Inhabiting Broxmouth: Biographies of a Scottish Iron Age Settlement. Unpublished PhD thesis, University of Bradford.

Büster, L., in press. Problematic stuff: reinterpreting structured deposits in Iron Age Europe. Antiquity.

Büster, L. \& I. Armit, 2013. Phase 6: the Late Iron Age village, in An Inherited Place: Broxmouth hillfort and the south-east Scottish Iron Age, by I. Armit \& J. McKenzie. Edinburgh: Society of Antiquaries of Scotland, 115-86.

Büster, L., K. Croucher, J. Dayes, L. Green \& C. Faull, 2018. From plastered skulls to palliative care: what the past can teach us about dealing with death. (Special Volume 3. Death in the Contemporary World: Perspectives from Public Archaeology.) AP: Online Journal in Public Archaeology 8(2), 249-76.

Campbell, E., 1991. Excavations of a wheelhouse and other Iron Age structures at Sollas, North Uist, by R.J.C. Atkinson in 1957. Proceedings of the Society of Antiquaries of Scotland 121, 117-73.

Carsten, J. \& S. Hugh-Jones, 1995. Introduction, in About the House: Lévi-Strauss and beyond, eds J. Carsten \& S. Hugh-Jones. Cambridge: Cambridge University Press, 1-46.

Croucher, K., 2018. Keeping the dead close: grief and bereavement in the treatment of skulls from the Neolithic Middle East. Mortality 23(2), 103-20.

Croucher, K., L. Büster, J. Dayes, L. Green, J. Raynsford, L. Comerford Boyes \& C. Faull, 2020. Archaeology and contemporary death: using the past to provoke, challenge and engage. PLOS ONE 15(12), e0244058.

Eriksen, M.H., 2016. Commemorating dwelling: the death and burial of houses in Iron and Viking Age Scandinavia. European Journal of Archaeology 19(3), 477-96.

Fernández-Götz, M., 2016. The power of the past: ancestral cult and collective memory in the central European Iron Age, in Funerary Practices during the Bronze and Iron Ages in Central and Southeast Europe: Proceedings of the 14th International Colloquium of Funerary Archaeology in Čačak, Serbia, 24th-27th September 2015, eds V. Sîrbu, M. Jevtić, K. Dmitrović \& M. Ljuština. Čačak: Boegard, 165-78.

Garrow, D., 2012. Odd deposits and average practice. A critical history of the concept of structured deposition. Archaeological Dialogues 19(2), 85-115.

Gell, A., 1998. Art and Agency: An anthropological theory. Oxford: Clarendon Press.

Gerritsen, F., 1999. To build and to abandon. Archaeological Dialogues 6(2), 78-97.
Gerritsen, F., 2008. Domestic times: houses and temporalities in Late Prehistoric Europe, in Prehistoric Europe: Theory and practice, ed. A. Jones. Chichester: Wiley-Blackwell, 143-61.

Gosden, C., 1997. Iron Age landscapes and cultural biographies, in Reconstructing Iron Age Societies, eds A. Gwilt \& C. Haselgrove. Oxford: Oxbow, 303-7.

Gosden, C. \& G. Lock, 1998. Prehistoric histories. World Archaeology 30(1), 2-12.

Gosden, C. \& Y. Marshall, 1999. The cultural biography of objects. World Archaeology 31(2), 169-78.

Hall, M.A., 2007. Playtime in Pictland: The material culture of gaming in Early Medieval Scotland. Rosemarkie: Groam House Museum.

Hamilton, D., J. McKenzie, I. Armit \& L. Büster, 2013. Chronology: radiocarbon dating and Bayesian modelling, in An Inherited Place: Broxmouth hillfort and the south-east Scottish Iron Age, by I. Armit \& J. McKenzie. Edinburgh: Society of Antiquaries of Scotland, 191-224.

Harris, O.J.T., 2010. Emotional and mnemonic geographies at Hambledon Hill: texturing Neolithic places with bodies and bones. Cambridge Archaeological Journal 20(3), 357-71.

Harris, O.J.T., 2016. Affective architecture in Ardnamurchan: assemblages at three scales, in Elements of Architecture: Assembling archaeology, atmosphere and the performance of building space, eds M. Bille \& T.F. Sørensen. London: Routledge, 195-212.

Hawkes, C.F.C., 1954. Archaeological theory and method: some suggestions from the Old World. American Anthropologist 56, 155-68.

Hill, J.D., 1995. Ritual and Rubbish in the Iron Age of Wessex: A study on the formation of a specific archaeological record. (BAR British series 242.) Oxford: Tempus.

Hillier, B. \& J. Hanson, 1984. The Social Logic of Space. Cambridge: Cambridge University Press.

Hodder, I., 2012. Entangled: An archaeology of the relationships between humans and things. Chichester: Wiley-Blackwell.

Hodder, I. \& C. Cessford, 2004. Daily practice and social memory at Çatalhöyük. American Antiquity 69(1), 17-40.

Hurcombe, L., 2007. A sense of materials and sensory perception in concepts of materiality. World Archaeology 39(4), 532-45.

Ingold, T., 2013. Making: Anthropology, art and architecture. London: Routledge.

James, H. \& R. McCullagh, 2003. Excavations at Hornish Point. Scottish Archaeological Internet Reports 3, 72-103.

Joy, J., 2009. Reinvigorating object biography: reproducing the drama of object lives. World Archaeology 41(4), 566-82.

Joyce, R.A., 2015. Things in motion: itineraries of Ulua marble vases, in Things in Motion: Object itineraries in anthropological practice, eds R.A Joyce \& S.D. Gillespie. Santa Fe (NM): Santa Fe Research Press, 21-38. 
Joyce, R.A. \& S.D. Gillespie (eds), 2015. Things in Motion: Object itineraries in anthropological practice. Santa Fe (NM): Santa Fe Research Press.

Kahn, J.G. \& J. Coil, 2006. What house posts tell us about status difference in prehistoric Tahitian society: an interpretation of charcoal analysis, sacred woods and inter-site variability. Journal of the Polynesian Society 115(4), 319-52.

Kay, K., 2020. Dynamic houses and communities at Çatalhöyük: a building biography approach to prehistoric social structure. Cambridge Archaeological Journal 30(3), 451-68.

Klass, D., P.R. Silverman \& S.L. Nickman (eds), 1996. Continuing Bonds: New understandings of grief. London: Taylor \& Francis.

Küchler, S., 1987. Malangan: art and memory in a Melanesian society. Man (n.s.) 22(2), 238-55.

Latour, B., 2005. Reassembling the Social: An introduction to Actor-Network-Theory. Oxford: Oxford University Press.

Matthews, W., 2004. Micromorphological and microstratigraphic traces of uses and concepts of space, in Inhabiting Çatalhöyük: Reports from the 1995-99 seasons, ed. I. Hodder. (British Institute of Archaeology at Ankara Monograph.) Cambridge: McDonald Institute for Archaeological Research, 355-99.

Maxwell, A.E. \& J. Oliver, 2017. On decentring ethnicity in buildings research: the settler homestead as assemblage. Journal of Social Archaeology 17(1), 27-48.

McLaren, D., 2013. Coarse stone, in An Inherited Place: Broxmouth hillfort and the south-east Scottish Iron Age, by I. Armit \& J. McKenzie. Edinburgh: Society of Antiquaries of Scotland, 309-33.

Meskell, L. (ed.), 2005. Archaeologies of Materiality. Oxford: Blackwell.

Metzler, J. \& C. Gaeng, 2005. Protohistoire, in Préhistoire et Protohistoire au Luxembourg: les collections du Musée national d'histoire et d'art, eds F. Le Brun-Ricalens, L. Brou, F. Valotteau, J. Metzler \& C. Gaeng. Luxembourg: Musée National d'Histoire et d'Art, 125-221.

Nakamura, C.M. \& P. Pels, 2014. Using 'magic' to think from the material: tracing distributed agency, revelation, and concealment at Çatalhöyük, in Religion at Work in a Neolithic Society: Vital matters, ed. I. Hodder. Cambridge: Cambridge University Press, 187-224.
Normark, J., 2009. The making of a home: assembling houses at Nohacacab, Mexico. World Archaeology 41(3), 430-44.

Ouzman, S., 2001. Seeing is deceiving: rock art and the non-visual. World Archaeology 33(2), 237-56.

Parker Pearson, M. \& Ramilisonina, 1998. Stonehenge for the ancestors: the stones pass on the message. Antiquity 72, 308-26.

Parker Pearson, M. \& C. Richards (eds), 1994. Architecture and Order: Approaches to social space. London: Routledge.

Sharples, N., 2010. Social Relations in Later Prehistory: Wessex in the first millennium BC. Oxford: Oxford University Press.

Stroebe, M.S., G. Abakoumkin, W. Stroebe \& H. Schut, 2012. Continuing bonds in adjustment to bereavement: impact of abrupt versus gradual separation. Personal Relationships 19(2), 255-66.

Taçon, P.S.C., 2004. Ochre, clay, stone and art: the symbolic importance of minerals as life-force among Aboriginal peoples of northern and central Australia, in Soils, Stones and Symbols: Cultural perceptions of the mineral world, eds N. Boivin \& M.A. Owoc. London: UCL Press, 31-42.

Tringham, R., 2000. The continuous house: a view from the deep past, in The Social Archaeology of Houses, ed. R. Samson. Edinburgh: Edinburgh University Press, $19-48$.

van Meijl, T., 1993. Maori meeting-houses in and over time, in Inside Austronesian Houses, ed. J. Fox. Canberra: Australian National University, 194-218.

Walter, T., 1996. A new model of grief: bereavement and biography. Mortality 1(1), 7-25.

Webley, L., 2007. Using and abandoning roundhouses: a reinterpretation of the evidence from LBA-EIA southern England. Oxford Journal of Archaeology 26(2), 127-44.

\section{Author biography}

Lindsey Büster is a Research Associate on the COMMIOS Project (Communities and Connectivities: Iron Age Britons and their Continental Neighbours) at the University of York. Her research focuses on ritual and domestic life in later prehistoric Europe, including non-normative funerary rites, complex and protracted relationships between the living and the dead, cave archaeology and the ritualization of everyday life. 